\title{
A Woman Unknown To Herself
}

\section{Joanne Tatham and Tom O'Sullivan}

School of Arts and Humanities, Royal College of Art, London, United Kingdom

Department of Arts, Northumbria University, Newcastle upon Tyne, United Kingdom

Dr Joanne Tatham

Reader in Contemporary Art

Tutor in Sculpture

School of Arts \& Humanities

Royal College of Art

Kensington Gore, London

SW7 2EU

joanne.tatham@rca.ac.uk

@TathamJoanne

Joanne Tatham and Tom O'Sullivan have been working together in a collaborative art practice since 1995. Joanne is a Tutor in Sculpture and Reader in Contemporary Art at the Royal College of Art. Tom is a Senior Lecturer at Northumbria University. Recent exhibitions include "A Proposal To Ask Where Does A Threshold Begin \& End" (2018) at MIMA in Middlesbrough, "A Successful Proposition for the Great North Exhibition" (2018) at BALTIC in Gateshead and "A petition for an enquiry into a condition of anxiety” (2016) at The Modern Institute in Glasgow. Joanne completed her undergraduate degree in Painting at Duncan of Jordanstone College of Art \& Design between 1990 and 1993, a time when Lil Neilson was a regular visitor to the art school. 


\section{A Woman Unknown To Herself}

This article is a fictional response to the paintings, sketches and notebooks left behind by the painter Lil Neilson $(1938$ - 1998) in her studio, The Watchie, after her death. The writing takes as its starting point the drawings and paintings that Neilson made in the last ten years of her life, when she returned to live in the coastal village of Catterline in Aberdeenshire. The title of the article is taken from a painting Neilson made in 19934. An extended, recomposed and adapted version of this text will be published as an artists' book The Bitter Cup in late 2019, commissioned by Book Works and Hospitalfield.

Keywords: Lil Neilson, painting, fiction, Scotland, art history, art writing 


\section{A Woman Unknown To Herself}

\section{The Lexicon}

I think I may have my lexicon.

It is a small spiral bound photographic album that contains details of sketches and paintings. Turning the page allows a particular rhythm to each reveal. The cumulative effect of the sequence feels useful, significant even.

I

A shape in a thick grey painted line. A circle in a divided square. The moon rising through a window or perhaps the head and shoulders of a figure, arms upheld in devotion. Areas filled in reddish black paint and a slash of scarlet across one half of the circle. The moon eye.

II

Again, a drawing of a circle in a square, this time the circle blocked out in purple against shades of brown, mauve and grey. The moon through the window.

III

A pattern of rectangular shapes drawn quickly in paint. Background areas of magenta and mauve. Some shapes outlined in blue and some filled in. One stands out as having been decorated with three pink stripes.

IV 
A pale moon in a blue sky. The landscape made up of patches of thick impasto: browns, blues and dark reds, the paint congealed and cracked. A shape below; a section of pale impasto that resembles the moon above. So, a seascape with the moon reflected.

V

Another moon. Thickly painted in white with a pattern of marks scraped into this lunar surface. This against a coal black night seen through a window. Below the window, the moon bleeds out to the lower edge. Looking closer I see the scrapes in these bleeding white marks. They are ears of corn.

VI

The moon is waning. A curved orange blade cuts the sky: one side black night, the other luminous white. A lozenge shape scraped into the white paint sits on the horizon. A second shape, scraped into black paint, sits in the foreground. A single black bowl on a table, its shadow cast by moonlight.

VII

The full moon rising above a field or the sea; the sky a dark ultramarine. Sections of yellow and cadmium red indicate a window frame and resting on the moon, a rectangular stump of congealed paint. Then the same material again below the horizon, as if a small chunk of land is lifting off with the moon.

\section{VIII}

The full moon, bright in layers of yellow and then white paint against the night sky. The reflection is pale grey in a white sea. Faint lines scratched into this white surface, like a ghost of an easel. On the right hand edge, a thick impasto of paint in a multitude of colours. A palette.

IX 
A repeat of $\mathrm{V}$. The ears of corn are clear. Is the moon crying?

$\mathrm{X}$

A striking white square against dark shades of red and yellow and Prussian blue. This sits on two smaller rectangles of white paint that jut up from the painting's lower edge. It may be a device for transmission or reception.

XI

A view of the harbour seen from above. A sweep of grey paint across the surface, with cerulean blue on each side as sky and sea. The waxing moon is a smear of white. In the foreground, an upright lozenge shape, painted with a palette knife in dirty red and burnt umber, which could be either obelisk or standing stone.

XII

A cube hovers in the foreground, painted in white over yellow, its shape delineated in crimson and cobalt. Behind this, like a series of windows, receding sections finally end in a small square of pale blue and deep orange, with the white cube repeated and turned the other way.

XIII

A large pool of white paint against dark tones of blue, red and viridian. At the top right another smaller circle of white paint surrounded with the glow of cadmium orange. From this, a line of white falls as if the moon is on a stick. Faint marks scraped into the larger pool of white. A face looking down.

XIV

The interior path leads to a centre of blinding light. On the left, a bird-like outline in palest leaf green emerges outwith a darker emerald panel. 
A horizon, and above this a white painted mark against pale blue. Below the horizon, two square sections. In one, a circular motif made up of swirling white marks, like a dish of snakes (is one of the snakes eating its own tail?). In the other section, a layering of colours, mostly blues. A view of rocks and a seashore.

\section{XVI}

A strange serpentine shape in black outline, tubular like a swan's neck. Below this, three hastily drawn spirals in yellow and what could be a pink rose. Behind this, rectangular areas like interior walls and a windowsill. On the sill a vase-like object outlined in green.

\section{XVII}

A streak of darkest indigo against whites. Small sections of orange, yellow and red surround. A landscape.

\section{XVIII}

A cauldron hangs on a hearth, its form scraped out from the surrounding paint. The flames are bright scarlet against the yellow surround. To the side of the hearth are two onions waiting to be added to the broth.

\section{XIX}

A figure reclines before the fire. The flames are scraped out of blue paint to reveal the orange surface beneath.

XX

Two illuminated rectangular spaces appear from a dark surround. Interiors within interiors. Within each space a shaft or shape of white light. One shape, like a shard of flint, is clearly outlined in black. They feel church like; sacred spaces, or perhaps reliquaries. 


\section{XXI}

A squat vase painted in heavy impasto holds several young shoots. The hyacinth. Behind this, seen through the window is the white light. On one side, a painted circular outline in palest manganese blue, on the other, a circle scraped into the white paint. The double moon.

XXII

The top half is a sequence of white squares upon a densely painted surface: window panes or the mosaic from the other place. The bottom half has the shape of a table and the sense of a hearth.

XXIII

The full moon, magenta in a blue sky. Beneath this the hyacinth is in heavy bloom on a crimson table. The spiral appears to the left like a piece of wrought iron.

XXIV

The moon appears in the top right, tightly enclosed in a square window. Below, an interior space of rectangular shapes and colour. White and lemon yellow cube-forms rest at the bottom edge. Paintings. A fluid shape outlined in quick black brushstrokes stands watching. 


\section{The Village}

The village is situated on the coast, seven miles south west of the small seaside resort of Whyme. Approaching the village via the main road offers drivers two possible routes, both of which pass pleasantly through farmland to the coast. For drivers heading north, the first of these two roads provides a narrow and meandering journey to its destination, and those taking a motor home to the small campsite on the cliffs just north of the village are advised to take the second of the two signposted exits. The two roads loop around opposing sides of The Lump, entering the village from either end and terminating in the small car park beside the primary school. Parking is free for those with a residents' permit, with a nominal charge (payable at an automated ticket machine) for visitors. Spaces in front of the cottages are reserved for residents and parking in the village is very limited. For non-drivers planning to visit the village the nearest railway station is at Fetterside, although services to Whyme are more frequent. Buses stop in the village twice a day.

The village lies in a slight dip before the cliffs rise again to the south, and the protection this affords from the worst of the south-westerly winds made this an attractive place for our ancestors to settle. Despite this, the village has never rivalled its larger neighbour to the north, and the largely eighteenth and nineteenth century buildings that line the clifftop are a slight legacy of the fishermen's boom years, when the village was at its most populous. In the twentieth century the population has dwindled and at the last census was recorded as less than 1,000 .

The focal point of village life is The Jackpot Inn, sited on the steep road that leads from the harbour to the cottages above. Other than that, there is a small but good quality grocers adjacent to the village's newest addition, a community centre built with European funds. Just beyond the village, the campsite also has a useful general store, although this is closed out of season.

The village can trace its history back to the Iron Age when the Celts founded a settlement. The presence of an Iron Age hill fort on The Lump is recorded in documents dating 
as far back as the seventeenth century, with a 1911 archaeological excavation of the eastern edge of the hillside uncovering evidence of ancient occupation. Neolithic artefacts, such as the flint arrows uncovered in the 1911 excavation, are now on display in Whyme's small Art Gallery \& Museum. In 1973 a further excavation at The Lump uncovered the Pelham pots, now in the British Museum in London. The pots show imprints of cereal seeds and are notable for providing evidence that the area was cultivated significantly earlier than previously thought. The smaller of the Pelham pots is quite elaborately decorated, whilst the others are much simpler in appearance. All are typical of early Neolithic pottery in that they were made by coiling clay and then smoothing down the sides.

The area along this particular stretch of the coast was also the site of significant activity during early Christianity, with finds of early carved stones dating to the eight and ninth centuries discovered in and around the remains of the small church that lies just beyond the village. The oldest surviving part of the church is the ninth century wall of the east crypt. Recent excavations on the ancient trench around the church found organic samples within a date range from $140 \mathrm{AD}$ to $590 \mathrm{AD}$, with evidence to suggest that the area enclosed by the ditch may have been an early settlement and craft-working centre.

Not surprisingly, given its coastal location, fishing and sail-making have long been an integral part of the life and economy of the village. Fishing boats have set sail from the cove for over 1,000 years, although by the nineteenth century fishermen had turned to smuggling to supplement their income. Despite the shelter afforded by the cove, landing a vessel wasn't without hazard, and in 1821 a short pier was built for further protection. This saw a boost to the fortunes of the village, with boats deserting the nearby village of Fisko for the safer new harbour. By the end of the first decade of the twentieth century, Fisko's inhabitants had followed suit, leaving their former home deserted.

As the twentieth century progressed the number of fishing boats began to dwindle, and there are now just a handful of working boats that drop anchor here. Whilst the population of the village itself has declined, the presence of the primary school ensures it maintains its status as a hub for the remote farms and cottages scattered across its hinterland. Numbers at the school 
have held steady as commuters, taking advantage of the upgraded A road, have returned to renovate the abandoned properties at Fisko.

The unique attractions of the area's topology and geology attracts both short and long term visitors, although heritage coast status has spared the village the worst of the modern developments that have appeared further along the coast. Other than The Jackpot and the caravan site there are few options for accommodation and most visitors arrive and depart the same day. These day-trippers may somewhat disrupt the otherwise tranquil air of the village, but are not altogether unwelcome and no doubt help to sustain the shop and pub.

The heritage coast extends for over 25 miles, beginning at Esten lighthouse north of the village, and reaching to the low hills that edge the Tooby estuary, where the landscape visibly changes. It defines an area rich in geological interest, with rocks from successively younger geological time periods gradually emerging into sight as one travels along the coast. The village itself sits at a point where Triassic rocks disappear below the sea, with the cliffs beyond the beach exposing the oldest Jurassic rock. These rocks were deposited in a moderately deep tropical sea packed with marine life and as a result fossils are very common. The unique rock formations have attracted geologists to the area to investigate and hunt for fossils for over 200 years. Bivalves and pencil shaped belemnites are very easy to find, coiled ammonites less so.

The community centre has a small display of local finds and a useful guide to fossil hunting in the local area that includes tide times. For those sufficiently interested, a more comprehensive fossil collection (including an ichthyosaurs discovered in 1849) is on show at the Heritage Coast Centre five miles to the south beyond Fisko. Please note, that the geology that makes the area so attractive to fossil hunters also poses a risk, with the cliffs around the headland in particular prone to movement. Landslips, such as the large slump of 1983, are likely to occur as a result of heavy rain and walkers are advised to always check the weather forecast.

The unstable cliffs south of the cove are an area of relatively undisturbed wilderness and are home to a rich array of plants and wildlife. The area was once used for grazing livestock, but now offers a dense tangle of trees, interspersed with native ferns and mosses. 
There are occasional sightings of deer, but visitors are more likely to hear their sharp bark as they bound into the undergrowth than they are to see them.

Its many attractions have long made the village a destination for painters and other creatives, and it acquired a reputation as something of an artists' colony during the earlier half of the twentieth century. In the 1960s a recognised school of painting emerged, which whilst less well known than those of St Ives or Kirkcudbright, still sees works by artists associated with the village achieving good prices at auction.

It was around this time that the tower that stands atop South Tap cliff was first converted into an artist's studio, and since when it has been in almost constant use as such to this day. There are no records to clarify when or by whom and for what purpose the tower was originally built, although there are numerous theories in substitute for evidence. My own theory is that the tower was built by the landowner for the very same reasons that it has proved so popular with painters and other artists, with its location and elevation providing both excellent light and unhindered views out to sea.

To a visitor arriving with images of painters in oilskins battling the elements on the harbour wall, the artistic life of the village may seem elusive. Nevertheless, a small community of creatives continues to work and live in and around the village. There is no gallery within the village itself, although the biennial arts festival is a popular recent local initiative. The festival usually takes place during the first week in August, and with venues such as The Jackpot and the community centre hosting events and exhibitions, this makes this an excellent time to visit the village.

\section{Evie}

I am Evie and I have fallen in love again.

Yesterday evening I had a curious experience of synchronicity. I'd been in the studio for an hour or so, looking at another of my long large paintings, and I was struck by a motif at the top left, a bird shape, outlined in red against muted blue. I was thinking about the painting as 
I left the building. I'd locked the backdoor and returned the key to its place under the water barrel when, turning to go, I saw something from the corner of my eye - a reddish brown shape in the sky just beyond the hedge. I stopped, then stepped slowly forwards for a clearer view. There was no mistaking the forked tail and markings. A red kite was hovering above the stubble, magnificent in the pale evening light.

I watched the bird for several minutes as it surveyed the field in a slow circular pattern. Then it moved across and over my head and made the same slow circle over the studio. He's looking for field mice, I said to myself, although I knew this didn't entirely ring true. The bird then returned to the field, making one last lap before disappearing into the copse of trees at the far corner. It was quite something to see such a bird so close. The coincidence unnerved me for the rest of the evening.

This morning I felt compelled to return and look again at my painting. The red bird appears hovering over a dense hedge of painted marks arranged in a vase. This is an interior space and the bird is being watched through the window. To the right of the bird the pyramid appears again, though here more like a hanging device and attached to a curtain painted in streaks of dusty pink, white and blue. This falls across the breadth of the canvas obscuring the view. Again that sense of concealment and potential reveal. Is this word play here? Is my curtain a kite, making the identity of the red bird certain?

Next to the curtain I had painted a tall mound of dark vermillion coils, like a serpent or worm twisted around a stick. The stick rests against what looks like a mantelpiece. The interior space is here, inside my studio. On the mantelpiece I placed a smaller object painted in stripes of yellow and green like a lizard, or some kind of ornamental pipe. Both objects feel sacred, ritualistic and constructed. Above the mantelpiece a section of horizontal landscape appears like a vision, the land pale and shaped like a dead leaf or long shard of flint, with careful markings along its length suggesting knapped facets and silvery veins. Two bulbs, or perhaps ears of corn, grow from this landscape, illuminated by a soft moonlight.

Below this mantelpiece there are three faces emerging from a thickly painted surface. The most prominent looks up from the bottom edge, the profile painted in a fluid black line 
against areas of green and white; a drowned face with a single emerald eye, blank and staring from the seabed. From its open mouth a crimson tongue outstretched as if tasting salt in watery surrounds. To the left, a second face, sketched quickly in blue, head thrown back in anguish and attached to a rudely painted stalk, as if an unholy flower. Finally, a terrifying skull, face on, teeth bared. The blackness of the right eye socket is the devastating centre to the painting. Are these three faces the three aspects of the psyche? The superego watching the ego in torment at the lascivious tongue of the id. In this interior space Ouroboros has been caught and eternal recurrence curtailed. This is the world of human subjectivity and it is in crisis, but outside of this catastrophe the red bird is hovering and the ancient landscape endures.

I am Evie and I was born at least 40 years ago and probably more, and what relation that has to what happened next I couldn't say, although I was always one of those children who knew what they wanted to be when they grew up. I wanted to be an artist, although I'll always bite my tongue when I say that, but it's still true.

I had the dream again last night. I am back on the coastal path between the village and the studio. The light is autumnal and everything seems to be illuminated from the inside. Again there is that strange sense of collapsed space and proportion. I stand on the path yet simultaneously inhabit the plants around me. I scrutinise a single elderberry or the hairs on a nettle leaf as if these are whole worlds.

I see the surface of the sea is slightly rippled as if stirring in a faint breeze. As I watch, a small area seems to become more and more agitated, as white crested wavelets break the surface. Slowly a pale object emerges. I know this object to be immense. I can see the streaks of water running off its sides and I feel a heaviness overcome me as if the light itself is exerting an enormous pressure. As the object emerges I can see it is a structure formed from an assemblage of tubular components. I cannot identify the material - it looks metallic but also has a soft translucency that glistens with a particularly intense silvery light.

As the structure becomes more and more visible it is clear that the main body is connected to another circular form. This feels of a different order and is a deep ultramarine bordered by a hoop of gold. A second curved shape is indicated towards the top, as if the tubular 
structure connects the two. Cords or cables coil out from the main column and then disappear back into the waves. I find myself saying the word hyacinth, and then white light. I know these phrases to be intimately connected to the structure and uttering them leaves me with a feeling of both excitement and peace. I wake and reach down to feel wet arousal between my legs.

The dream obviously has a relationship to the drawing I pinned up in my kitchen. I think my unconscious understands the flower in this drawing as some kind of a device to emit or receive white light. The angular shapes in the drawing must connect with very deep memories of fantastical and unknowable machines and I recall the scribbled sketches I produced as a very small child. The shapes also suggest something crystalline; white light refracted through a crystal. A crystal set. Again, that strange sense of transmission or reception. I am Evie and I remember everything so clearly and vividly.

In front of me are two canvases of an intense hallucinatory nature. Each has a triangular motif that sits along the bottom edge, and in each there is a tonal play of colour, creating distinct planes of dark and light. Both are pierced by shafts of yellow and white, which have such luminosity against the dark surround. These triangular areas are foreshortened pathways towards an interior. Each path comes to its end in the centre of each canvas. In one this is a blinding bowl of white light. The destination as an epiphany or transformation.

In the other painting the path has planes of crimson and orange, thickly painted and with areas of white paint scraped over with a palette knife. The path leads to a tree painted in pink and white and outlined in earthy brown like a freshly ploughed field. A rectangle of winter sky, in watery blue and smeared pink, provides a window back into the conventional world.

A white shape on the left is another tree, or a figure with arms raised in devotion. On the right two grey shapes, one light, one dark, and one within the other, form a structure or enclosure. This is my studio viewed from far above. Above this, the horizon bisects the canvas and creates a scene constructed from conflated and expanded viewpoints.

The full moon is centred in a cloud above the horizon. It is an eye looking down with a pupil slit of deep magenta. This, against ominous grey, gives a nightmare cast. A droplet of viscous material runs down the picture plane from the top right-hand corner, a single strand of 
pale funghi that echoes the devotional figure opposite. There is a realism to these paintings, but this is in relation to an unknown interior world. I may have created them but I remain on the outside. I observe rather than participate.

I've been considering whether to take a small dose of psilocybin. A few days ago I spotted the unmistakable silky brown cap and nipple of liberty caps poking up through the damp grass on the studio lawn and I wondered what might be revealed if this produced a mind state analogous to these paintings.

I am Evie and I was born some distance away and some time ago now and that's quite a statement. I'm not so sure what that has to do with what follows or the decisions I made in my life as I lived it. I've always been curious and creative but I've never wanted to settle down and be one thing or another. I've made many decisions and had many made for me too.

When I was a child my parents bought me a little paint box, one of those white watercolour ones, with little squares of colour. I remember soon getting bored of this though and I would prise the colours out one by one using the blade of a little screwdriver I'd got in a Christmas cracker! At school I would enjoy reaching into bags of powder paint and the wonderful feel as the scoop sliced through the soft cloudy colour. The paint itself was disappointing, all gritty and watery. I soon moved onto better things, buying oil paints and linseed oil at the age of eleven and I remember how impressed my art teacher was. It was about that time that I started to go to the library and borrow the big books from the lower shelves.

I loved Van Gogh and thinking about those thick swirls of colour kept me busy. I tried all the ways I could to paint the moon and also more ordinary things around my parents' house. At school we sat at a long high table on wooden stools and the other pupils said I was good at art. My teachers thought I might become a teacher and I was very good at geography. I liked to think about the mountains and the lochs that were my world at that time. I set up a big table in my bedroom at home and kept painting and my art gave me a window on a world beyond my parents' house and the small town I grew up in. 
When I got my Highers I was finally able to go to art school and that was the start of my life now and I was among people who were as eager for knowledge as I was. We arrived at our studios in the morning and we stayed in the evening as late as we could. It wasn't long before I fell in love. Everything felt alive and art was the whole world for me. It's twenty-five years after all of this now and a lot has happened since then. I imagine there may yet be many more changes to come.

A strange thing happened earlier today. I was down at the beach for an evening stroll and decided to cut across to the cliffs beyond the harbour. There' $\mathrm{d}$ been a recent collapse and I was curious how the trees would adapt to their new terrain. I headed up the edge of the bank away from the village and before long I was at the edge of the woods. In the diminishing evening light I found myself confronted by an impenetrable wall of green. I walked in and it was indeed quite dark and considerably cooler than the open space I'd just left. I made my way slowly inwards through tangles of branches and upended roots. The collapsed cliff terraces reached further than I had anticipated. I was soon quite a way from both the sea and the village. I felt deep within a dense silence broken only by the sound of my own progress over snapping twigs.

After twenty minutes or so I stopped to catch my breath. I looked up and there on the slight incline ahead was a young roe deer, staring straight at me. I stood still and for several seconds the two of us stood looking at each other. I made a slight movement with my leg, expecting the deer to flinch and then dash. Nothing happened. It stayed stock-still. Somewhat amused I called out to it and waved. Again, it made not the slightest move. Then, a queer feeling that the creature was knowingly preventing me from moving forward. I stepped back a couple of paces and turned around and began to walk away. After a few minutes I began to feel a little foolish and flushed about what had just happened, but I kept walking until I resumed my usual route home.

Odd. The thing I realise now, and what must have caused that feeling, was that the deer had the same look as the hare in my painting. I don't mean that they had the same appearance, it 
was more that they looked the same way at me. It was as if I was trespassing too close to a threshold I shouldn't enter.

When I was a child I was always so full of things I wanted to make or pictures I wanted to paint. I used to write too - poems and stories and silly little skits. I'd sit in my bedroom and write and I'm not sure I ever intended to show anyone. I remember I was a practical child, or at least I liked to think so. I liked to find out how things worked and I enjoyed helping my Dad fix things around the house. I'd spend the morning helping him plumb in a radiator or put up a shelf. These things are all relevant to me now and are all part of what I do.

I saw the tree again today. The same tree, only this time painted with more verisimilitude. It is one of the larger trees in the immediate vicinity of the studio. A translucent globe surrounds the branches, the edges picked out in dabs of white paint. The whole edifice is sparkling; it is clearly sacred. It has also been pollarded and there is a resistance in this. Despite this intervention to constrain and shape the tree, it still remains luminous. Beside the tree, a white circle within the mottled mauve sky is both the sun about to set and the full moon rising, and this dual nature infuses everything with an uncertain glow.

I painted the tree roots in cross section through the earth. Tendrils of thick cobalt, crimson, white and black penetrate deeply, echoing the branches. Towards the base of the tree, layers of landscape appear as field shapes of ochre in stubble and ploughed earth. A landscape farmed for generations. Land that provides sustenance in the cycle of death and rebirth.

I painted one of the rocks that looms off the headland but its appearance here feels more akin to the mythical isles of Lyonesse or Hy-Brasil. Below this, woven together like tapestry, I painted a dense bed of meadow grass or reeds, picking out stems, leaves and flower heads in white impasto. At the top right a white bird flies into another space and background and midground collapse into the surface of the painting. A pattern of feverish shapes, like amoeba or mushrooms, takes over. The foreground is a chaos of marks with areas of raw canvas. The language of paint is broken down and laid bare. I painted an upturned boat in bold red paint. Below this the boat shape repeats, indicating water. The boat is at rest below the reeds. The traveller within is safe, cocooned underneath and inside. 
There is that sense of concealment again. I think this is the central subject of the painting and I remember as a child seeing a beautiful wooden box in the window of an antiques shop. I remember how the box opened out with hinged folding shelves stretching out wide from the base. I was six or seven. The shelves extended to reveal orderly rows of oil paints and paint brushes and many other tantalising things. At my next birthday my parents bought me my own box and inside this were gouache paints and brushes. I had many happy hours arranging the colours this way and that, and thinking about the paintings I would paint.

I knew from a young age that I wanted to go to art school and I wanted to go to London, but instead I went to Dundee. It was cheaper there and I'd liked the huge blue skies and the golden light when I'd visited. It was May and I was probably in love with someone. I was allocated a place in halls on the edge of the town, high on a hill and with views of the Tay. When I arrived I began to feel anxious about those wide open skies and there was too much space and emptiness around me. Later, the light and the brightness became a familiar source of exhilaration. That was the beginning of my life in Scotland.

It's evening now and I've returned to the studio to look at the new painting. I have a feeling that the change of light might change how I see it, or might grant me access into its own inner world. It's here, just as I left it, propped up against the easel (why would it have moved?). The serpent still has that strange translucent quality, the body painted with both brush and palette knife, with white paint smeared and dappled along its length. These marks, against washes of green and blue, create the effect of scales and sliminess and I'd painted shards of rainbow amongst all this, as if the serpent's skin was a prism breaking up the light cast on it. This is Ouroboros - but to what end?

Retreating triangular planes provide a landscape of pyramids on which the Ouroboros turns. In front of this a sequence of spirals brings to mind the cup and ring petroglyphs of prehistoric stones. Its painted body gives the creature an unhealthy pallor. The mouth eats the tail against a background of driving rain. This is an Earth-bound Ouroboros, caught in its own circle of endless return. 
In the right-hand corner a full moon gives the scene its luminosity. It's a garish pink moon painted roughly within a pastel lemon halo and clasped by crescents of violet and viridian. The three ripe ears of corn on the left had side indicate that this is the Harvest Moon. It is the Autumn Equinox, a time of light and dark both held in the balance. I see a black eclipse above the ears of corn and the bright moon. At this still turn in the year Ouroboros appears as a marriage of oppositions. The white bird soars towards the serpent and my brushwork, gestural and schematic, declares that this is the spirit in flight and a counter-balance to the earth-bound serpent. Behind and above this are letters and numbers and mosaic squares, all painted with the same gestural marks in shades of white. A, L, S, G. There is an indistinct sequence of numbers and a calendar of some sort. The bird becomes a figure within this text. I feel it is hermetic in nature but its meanings continue to elude me.

The surprise is what sits within the Ouroboros ring. Scraped into a square of white paint are five shapes, cuboid in character and done with quick jerks of the palette knife. They stand out sharp and bright against the dark interior. The building blocks of representation, but so slapdash as if this whole edifice is to be disregarded. Is this, then, the heart of the matter; to turn one's back on painting and instead embrace the numinous nature of the world?

\section{Appendix: works for sale}

\section{Paintings}

A Bird in the Dawn $£ 350$

Low Tidings $£ 400$

Woman and the Sea $£ 450$

The Black House $£ 450$

I Remember my Name $£ 275$

My Moon $£ 550$

An Uncertain Row $£ 150$

Last Day $£ 200$ 
Magpie’s Myth $£ 450$

The Short Creek $£ 200$

Deluge $£ 150$

Black Cat and a Mirror $£ 500$

The Night Not Known $£ 250$

Sleep at Noon $£ 200$

Small Skulls £175

An Animal Virtuoso $£ 350$

Ash and Elm $£ 225$

The Landings $£ 350$

Green Curtains $£ 250$

Crow and Moon $£ 425$

January $£ 400$

Neither Being (Nor) £325

Three Women and a Boar $£ 650$

Blue Eyes $£ 275$

Overtown $£ 175$

Sketches and collages

Last Year's Dream (I) $£ 85$

Last Year’s Dream (II) £85

Last Year’s Dream (III) $£ 85$

Cobbles $£ 60$

You Always Knew $£ 100$

Chinese New Year $£ 55$

Iris $£ 65$

Gull Line $£ 50$

Canute / Newt Emerging £75 
My Moon (Study 1) £90

Harbour Stepping $£ 65$

Sea Pinks $£ 65$

Margret £85

An Eruption (Deep Base) $£ 90$

Red Socks $£ 40$

Screen-prints

Pots and Plates I $£ 45$

Pots and Plates II $£ 45$

Ancient Beasts series I-VI $£ 30$ each

Harvest Sky s£50 
Acknowledgements:

We would like to acknowledge both Book Works and Hospitalfield for the commission to develop The Bitter Cup. We would also like to acknowledge the kindness and generosity of Ann Stead, friend of Lil Neilson and custodian of her studio.

References:

Buchanan, Frances. Images Insisting: An exhibition of Paintings \& Prints by Lil Neilson (1938 - 1998). Glasgow: Mansfield Park Gallery, 2004.

Hooper, Rosie. “Lil Neilson”, Herald, 13 January 1998.

https://www.heraldscotland.com/news/12282327.lil-neilson/

Melville, Jennifer. Certain Days and Other Seasons: Lil Neilson. Aberdeen:

Aberdeen City Council, Arts \& Recreation, 1996.

Steed, Ann. Into the Light: The Art of Lil Neilson. Aberdeen: Aberdeen City Council, Arts \& Recreation, 1999.

Figure 1. Joanne Tatham and Tom O’Sullivan, Untitled (The Watchie), 2013.

Figure 2. Lil Neilson, A Place for 4 Women. Photograph by Joanne Tatham and Tom O’Sullivan, April 16, 2019, Catterline.

Word count: 6622 